\title{
Aspects of Development of Accumulative Life Insurance and Investment Insurance in the Russian Federation at the Present Time
}

\author{
Lyusiena Evgenyevna Piunko
}

\begin{abstract}
Department of mathematical methods and information technologies Far-East Institute of management, Branch of the Russian Presidential Academy of National Economy and Public Administration (hereinafter RANEPA), FEIM, branch of RANEPA, Khabarovsk, Russia

Corresponding author. Email: lusiena_03@mail.ru
\end{abstract}

\begin{abstract}
The market for accumulative and investment life insurance in Russia and its regions, including the far Eastern Federal district, is only developing, or rather reviving, after its disappearance due to the collapse of the USSR. Today, insurance companies are developing and implementing products in the field of voluntary accumulative and investment life insurance. For the sector of accumulative and investment insurance, it is very important to develop digital platforms for interaction with customers and, perhaps, even more work. to explain to the population about the importance of independently forming financial reserves through savings and investment insurance products; and on the part of the state - control over participants in the insurance market, protecting them from fraudulent schemes, as well as the formation of measures to support bona fide insurance companies in promoting their products of savings and investment life insurance. It is very important to increase the financial literacy of the Russian population, and increase their personal responsibility for their own future, the formation of financial discipline and their own financial reserves, including using existing insurance mechanisms
\end{abstract}

Keywords: personal insurance, cumulative life insurance, investment life insurance, insurance market

\section{INTRODUCTION}

Over the past ten years, the Russian insurance market has undergone many changes: the change of the insurance regulator, the transition to IFRS in reporting, stricter requirements of the Central Bank to the reserves of insurance companies, the "cleansing" of the insur-ance market from unscrupulous companies, sanctions of Western partners, problems of the reinsurance market, and much more. In the West of Russia, there are all these difficul-ties, and the financial insurance sector is currently solving them; and in the Far Eastern Federal district, all these problems are compounded by the outflow of population from the region, low population density, the lack of competitive local insurance companies, and poor public awareness of possible insurance tools for protection and investment.

\section{METHODOLOGY}

In this study, we applied research on indices of quantitative indicators of insurance, in relation to types of personal insurance; and also studied individual indices of life insurance in the far Eastern region. A comparative analysis of the total values of insurance volumes by type, both for Russia as a whole, and the values of insurance indicators for Moscow, was made.

\section{PREREQUISITES FOR THE DEVELOPMENT OF THE SYSTEM OF ACCUMULATIVE LIFE INSURANCE IN THE RUSSIAN FEDERATION}

Issues of digitalization of the social sphere and its component, such as mandatory social insurance in the development of the digital economy, are relevant today, as are issues of digitalization of the voluntary insurance sector. The government of the Russian Federation is developing programs for the development of insurance systems $[1,2]$ in the digital economy; state institutions are developing mechanisms and instructions for modernizing the processes of providing insurance services to the population and legal entities, both for mandatory and voluntary insurance. 


\subsection{Participation of Western insurance companies in accumulative life insurance of Russian citizens}

Western insurance companies, for example, such companies as Medlife - GRAWE group insurance company, Unilife life insurance company, etc. actively use Internet services for customer service remotely, although all agreements, changes to agreements, and applications are processed by the insurer only on paper, with the mandatory indication of a special customer code (or service agreement). Medlife, Unilife and others like them are actively working on concluding cumulative life insurance contracts in Russia and the former Soviet Union.

In addition to Internet services, Western insurance companies are actively promoting their insurance products, especially in terms of cumulative life insurance. And, the terms of insurance contracts of Western insurers, it should be noted, are really very attractive: insurance is carried out in the currency that is least susceptible to inflation; a system of bonuses and additional premiums is used during the formation of the cumulative amount under the contract. Even the fact that the Russian insurance system is not used to - payment for the services of the insurer for the registration of the contract and account maintenance-does not significantly affect the preference of the Western insurance company in matters of cumulative life insurance over domestic (Russian) insurance companies [3, 4].

It should be noted that Russian insurance companies have been trying to develop accumulative and investment life insurance over the past ten years. Given the uncertainty of the Russian pension insurance system and all the risks of accumulative pension insurance, additional tools such as investment life insurance and accumulative life insurance, as well as parallel support for the financial well-being of Russians in their pre-retirement and retirement years, should attract them to the Russian insurance sector; increase their responsibility for their own future.

But this is not observed. Today, mandatory and property insurance is actively developed, the share of personal insurance and voluntary insurance is small (mandatory pension and mandatory medical insurance will be taken out of the brackets of this study for the time being). This is due primarily to such factors as: quality of life of the population, financial literacy, financial discipline of the population, the debt load of the population, a separate "national" attitudes of the population to have "everything at once", as well as mapping their material well-being with neighbors, friends, relatives (here are the main expenses of the population for the purchase of housing mortgage, car purchase loan, the purchase of expensive goods on credit). Very often, financial organizations when it is impossible to implement programs for repayment of credit and mortgage loans, face a situation that the borrower during the period of obtaining a loan (loan) was trustworthy, with high financial discipline, but during a long period of repayment of borrowed funds suddenly fell ill, or lost his job, having no savings, can not continue to pay for the loan or loan (most often, mortgage).
Thus, individuals, while they are able to work, are full of energy, have a permanent job, do not even predict the situation when due to illness or loss of work, or the loss of other sources of income, and therefore do not care about creating their financial "safety cushion". At the same time, we are talking not only about saving money on deposits, or using investment accounts, but also about such a very convenient and relatively safe tool as insurance. First of all, accumulative life insurance.

Russian citizens with higher-than-average incomes try not to take out large loans with a long repayment period. Representatives of this class either participate in the lending system, but short-term and with small amounts, or do not take loans at all, preferring, moreover, to save money through deposits. Thus, the classic premise of Keynes that the higher the income of citizens, the less they are prone to waste and the more they accumulate financial resources, works surprisingly well here. Representatives of the Russian middle class also use the tools of accumulative insurance, but at the same time, preferring to carry out insurance with Western insurers in foreign currency, i.e. withdrawing money abroad, which is not safe under the existing Western sanctions. Some Western insurance companies are located in offshore zones, for example, on the island of. Cyprus. The actions of certain Western insurers that promise a multiple income in relation to the invested amount can be qualified as the activity of a financial pyramid. despite all the risks, Russian citizens prefer Western companies when choosing accumulative life insurance.

\subsection{Activities of Russian insurance companies in the direction of accumulative life insurance for citizens of the Russian Federation}

The majority of citizens in Russia do not use the tool of accumulative or investment life insurance at all. Note that modern Russian insurance companies offer a variety of products in the field of accumulative and investment insurance, including life insurance.

Internet platforms used by major domestic insurers such as Sberbank-insurance, VTB-insurance, Ingosstrakh, etc.are more informative, clear and convenient in terms of posting information about insurance products, insurance conditions, all sorts of approximate calculators of insurance premiums and payments, and, importantly, have a higher degree of protection. For example, when you go to the Internet address of Sberbank-insurance and VTB-insurance companies, the system switches to the anti-virus protected login mode in both cases. Of course, it is not correct to generalize on the example of two Western companies (Medlife and Unilife) the comparative characteristics of the information content, convenience and security of their Internet platforms with the Internet services of domestic insurance companies and is not the purpose of this article. In this case, I would like to note that the development of digital services for insurers in Russia is not inferior to digital Western services, and sometimes even outstrips 
them; while the volume of capital of Russian insurance companies can not yet compete with the capital of Western insurers $[5,6]$.

The Russian government is clearing the insurance market of unscrupulous insurers under the supervision of the Central Bank of Russia. A program to protect individual savings insurance programs will be launched very soon. To protect citizens ' money invested in life insurance, a system similar to Bank Deposit insurance is being developed. It is expected that it will work in Russia in 2021. The insurance companies themselves, which are licensed to carry out accumulative and investment insurance, are usually subsidiaries of large banks with state participation. And despite all these measures, the population is not involved in this insurance sector on a large scale. Accordingly, the segment of the accumulative insurance market cannot develop dynamically and positively, since it is low (or almost absent) the demand for the services of life insurance. Thus, at present, Russian citizens resort to the services of Western insurers in terms of cumulative life insurance, or do not use this tool at all. The most famous among Russians are such Western insurance companies, such as Medlife insurance company of the Grawe concern, life insurance company Unilife [5, 6], and a number of quite large Western insurers. At the same time, for example, the GRAWE concern has a solid reputation and a long history of its activities, perhaps this reputational aspect is one of the determining factors in the choice of an insurance company by citizens who are concerned about the financial well-being of themselves and their loved ones in the future. In General, objectively assessing the digital infrastructure of insurance companies, primarily domestic ones, we can conclude that they successfully integrate into the digital environment and operate successfully in the digital economy. At the same time, the state institutions involved are building their activities in the insurance sector from the position of fulfilling social obligations to citizens, as well as creating a convenient and affordable social insurance environment, its effective work in achieving the goals of social protection of the population (including mandatory pension and mandatory medical insurance systems).

The current difficulties of insurance companies in the field of accumulative and investment insurance are primarily related to the formation of reserves and compliance with the conditions for their solvency. At the same time, the vague concept of investment insurance, its unclear wording on risks and investment income, sometimes not quite clean conclusion of investment insurance contracts with citizens, can cause General frustration of citizens in this product and a drop in market volumes. Thus, it turns out a vicious circle: insurance companies need to attract citizens ' money savings to their reserves, ensure that this money is stored in insurance companies within the framework of contracts without the possibility of their withdrawal by insurers before the contract term, calculate the risks associated with the occurrence of insurance events (provide them with their own reserves), faithfully fulfill all obligations assumed; carry out investment activities in such a way that the reserves do not decrease, but only increase; and thus, the reluctance of citizens to agree on the condition that they will not be able at any time to withdraw your money back, reluctance of citizens to perform investment agreements in the long term; sometimes sharp fluctuations of the national currency on the world market; the sanctions pressure from Western countries, the problems of the Russian reinsurance market - all this hinders the development of investment insurance, and a funded personal insurance.

\section{RESULTS AND DISCUSSION: MEASURES TO OPTIMIZE THE CUMULATIVE LIFE INSURANCE MARKET IN THE RUSSIAN FEDERATION}

\subsection{Analysis of the market share of cumulative life insurance in Russia and the far Eastern Federal district}

The Russian insurance market is developing, and over the past five years has suffered a lot of shocks: sanctions, which were imposed on Russian insurers, the change of the regulator, the transition to the international financial reporting system (IFRS), in the light of the fact that the market has a lack of qualified specialists who can prepare reports in accordance with IFRS (the formation of an insurance company's accounting policy in accordance with the requirements of IFRS is now mandatory); introduction of a list of regulations by the Central Bank of Russia [7] concerning control in the sphere of insurance activity; problems of the reinsurance market (lack of reinsurance capacities) and some other challenges that require insurers to solve them immediately [8-11].

Insurance premiums (contributions) by insurance category in 2018

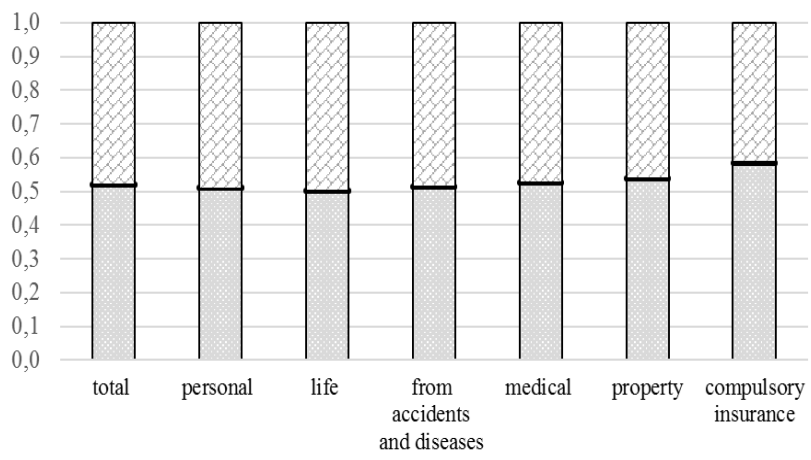

$\square$ Russian Federation $\quad$ Eastern federal district $\square$ Moscow

Figure 1 Insurance premiums (contributions) by insurance categories collected by insurers (million rubles) in $2018[7,12]$

* The diagram was compiled by the author based on Rosstat data [12-14] 
Table 1 Total insurance premiums of insurers by individual insurance segments in russia and in the subjects of the far eastern federal district in 2018 [12]

\begin{tabular}{|c|c|c|c|c|c|c|c|}
\hline \multirow[b]{3}{*}{ Regions } & \multirow{3}{*}{ 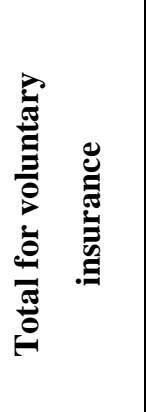 } & \multicolumn{4}{|c|}{$\begin{array}{l}\text { On a personal voluntary basis } \\
\text { insurance }\end{array}$} & \multirow{3}{*}{ 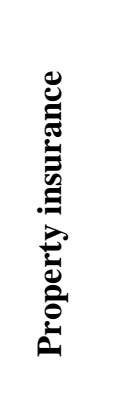 } & \multirow{3}{*}{ 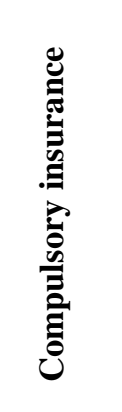 } \\
\hline & & \multirow[b]{2}{*}{$\begin{array}{c}\text { Total } \\
\text { personal } \\
\text { insurance }\end{array}$} & \multicolumn{3}{|c|}{ by type: } & & \\
\hline & & & $\begin{array}{c}\text { Life } \\
\text { insurance }\end{array}$ & $\begin{array}{c}\text { Accident } \\
\text { insurance } \\
\text { cases and } \\
\text { diseases }\end{array}$ & $\begin{array}{l}\text { Voluntary } \\
\text { medical } \\
\text { insurance }\end{array}$ & & \\
\hline $\begin{array}{c}\text { Russian } \\
\text { Federation }\end{array}$ & 1228813 & 774630 & 452296 & 170006 & 152329 & 454182 & 259275 \\
\hline $\begin{array}{c}\text { Moscow } \\
\text { (comparatively) }\end{array}$ & 1136595 & 748403 & 449927 & 161225 & 137250 & 388192 & 183958 \\
\hline $\begin{array}{c}\text { Eastern federal } \\
\text { district }\end{array}$ & 2410,3 & 987,1 & 526,9 & 216 & 244,2 & 1423,1 & 1876 \\
\hline $\begin{array}{c}\text { The Republic of } \\
\text { Buryatia }\end{array}$ & - & - & - & - & - & - & - \\
\hline $\begin{array}{l}\text { The Republic Of } \\
\text { Sakha (Yakutia) }\end{array}$ & 1422,8 & 161,7 & - & 120,8 & 40,9 & 1261,1 & 1875 \\
\hline $\begin{array}{l}\text { Zabaikalsky } \\
\text { region }\end{array}$ & - & - & - & - & - & - & - \\
\hline $\begin{array}{c}\text { Kamchatka } \\
\text { territory }\end{array}$ & 43,2 & 0,7 & - & 0,7 & - & 42,5 & - \\
\hline $\begin{array}{l}\text { Primorsky } \\
\text { region }\end{array}$ & - & - & - & - & - & - & - \\
\hline $\begin{array}{c}\text { Khabarovsk } \\
\text { territory }\end{array}$ & 944,3 & 824,8 & 526,9 & 94,6 & 203,3 & 119,5 & 0,9 \\
\hline Amur region & - & - & - & - & - & - & - \\
\hline $\begin{array}{l}\text { Magadan } \\
\text { region }\end{array}$ & - & - & - & - & - & - & - \\
\hline Sakhalin region & - & - & - & - & - & - & - \\
\hline $\begin{array}{c}\text { Jewish } \\
\text { Autonomous } \\
\text { region }\end{array}$ & - & - & - & - & - & - & - \\
\hline $\begin{array}{c}\text { Chukotka } \\
\text { Autonomous } \\
\text { Okrug }\end{array}$ & - & - & - & - & - & - & - \\
\hline
\end{tabular}

\footnotetext{
* The table was compiled based on Rosstat data [12-14]
} 
Consider the ratio of cumulative life insurance, the share of personal life insurance, in comparison with property insurance and in comparison by region. Since the author is more interested in the far Eastern Federal district of Russia, because of its territorial coverage of more than a third of the entire territory of Russia and at the same time, as the most depressed from the point of view of economic development of the region.

\subsection{Analysis of insurance market indicators in Russia, the far Eastern Federal district and Moscow}

A number of cumulative life insurance products that life insurers sell today are slightly transformed investment life insurance policies. Moreover, some banks have adopted the practice of concluding investment life insurance contracts under the guise of making deposits with financially untrained citizens, which can only be terminated unilaterally without financial losses for the policyholder during the cooling off period (the first fourteen days from the date of conclusion of the agreement), and in practice, individual insurers and this is not always fulfilled.

Referring to the data of the Federal state statistics service in the field of insurance activity, regarding personal insurance and life insurance, Rosstat does not share the data that reflect, for example, mandatory life insurance for mortgage lending and mandatory life insurance for employees of hazardous industries, however, according to Rosstat data, you can see the dynamics of collected premiums for life insurance and personal insurance (figure 1, table 1) [13, 14]. It is obvious that almost the entire share collected on insurance premiums is redistributed in Moscow, because the legal addresses of most major insurance companies and their main offices are located in Moscow.

Comparing statistical reports, it can be seen that for Moscow, the share of collected insurance premiums is $89 \%$ of the national value, and the share of payments for all insurance contracts, including both mandatory and optional, personal and property $-29 \%$ of the national value.
Individual performance indicators of insurers(insurance premiums and payments under contracts, million rubles) in 2018

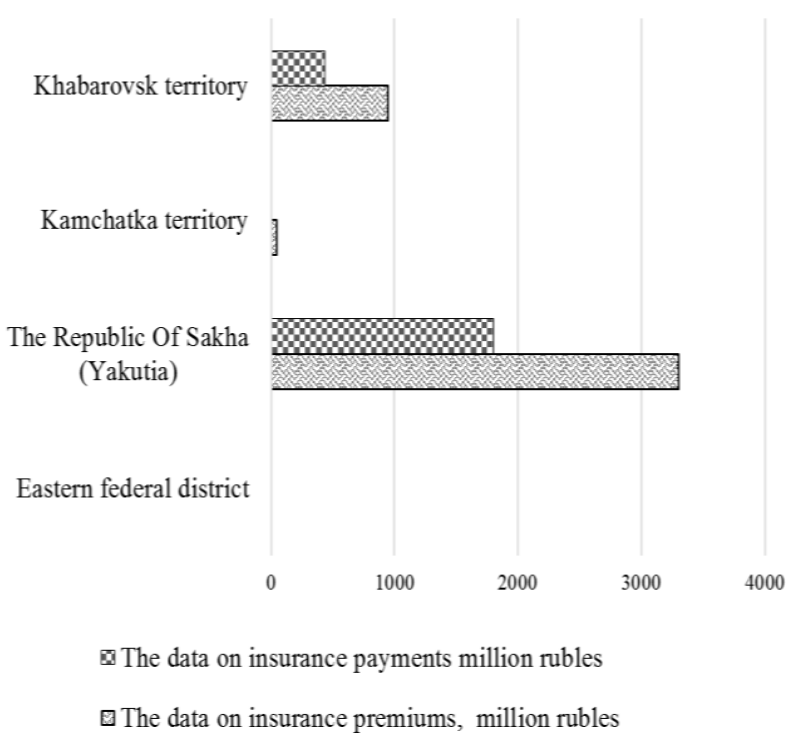

Figure 2 Performance Indicators of insurers for individual subjects of the far Eastern Federal district in 2018 [12-14]

* compiled by the author according to Rosstat $[12,15]$

At the same time, the main "donor" in the insurance system of the far Eastern Federal district is the Republic of Sakha (Yakutia) - shown in figure 2 (the histogram is built by the author on the basis of Rosstat data) $[12,15]$.

Analyzing the clusters of insurance in the far Eastern Federal district (shown in figure 2 and table 2), it is obvious that the leading sector is property insurance, and this is mainly CTP $[13,16]$, with a small share of mortgage insurance and CASCO; housing insurance (apartments and property in them), the property of enterprises is too small; in second place is personal insurance, but this share is achieved through mandatory personal insurance. In General, the main region in the ratio of received insurance premiums and payments for the far Eastern Federal district is the Republic of Sakha (Yakutia), despite the fact that the share of property insurance is a multiple of the share of personal insurance (figure 2). In the far Eastern Federal district, life insurance, if compared with Russia as a whole, and with Moscow, is almost not developed. This is mainly due to poor financial literacy, and the quality of life of the region's population, which is lower than the average for Russia. And another factor is the outflow of population from the territory of the far Eastern Federal district to the Western regions, hence the redistribution of financial flows in insurance, including life insurance. 
Table 2 Share of voluntary insurance of the far eastern federal district by individual insurance segments to the all-Russian indicators and to Moscow in $2018[12,13,16]$

\begin{tabular}{|c|c|c|c|c|c|c|c|}
\hline \multirow{3}{*}{ Regions } & \multirow{3}{*}{ 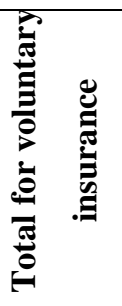 } & \multicolumn{4}{|c|}{$\begin{array}{l}\text { On a personal voluntary basis } \\
\text { insurance }\end{array}$} & \multirow{3}{*}{ 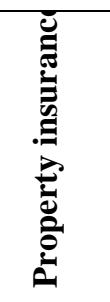 } & \multirow{3}{*}{ 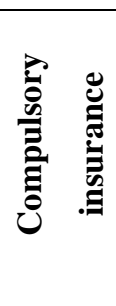 } \\
\hline & & \multirow{2}{*}{$\begin{array}{c}\text { Total } \\
\text { personal } \\
\text { insurance }\end{array}$} & \multicolumn{3}{|c|}{ by type: } & & \\
\hline & & & $\begin{array}{c}\text { Life } \\
\text { insurance }\end{array}$ & $\begin{array}{c}\text { Life } \\
\text { insurance }\end{array}$ & $\begin{array}{l}\text { Life } \\
\text { insurance }\end{array}$ & & \\
\hline $\begin{array}{c}\text { The share of } \\
\text { insurance } \\
\text { indicators of the } \\
\text { Far Eastern } \\
\text { Federal district to } \\
\text { the values for } \\
\text { Russia }\end{array}$ & $0,20 \%$ & $0,13 \%$ & $0,12 \%$ & $0,13 \%$ & $0,16 \%$ & $0,31 \%$ & $0,72 \%$ \\
\hline $\begin{array}{c}\text { The share of } \\
\text { insurance } \\
\text { indicators of the } \\
\text { Khabarovsk } \\
\text { territory in } \\
\text { relation to } \\
\text { Moscow }\end{array}$ & $0,08 \%$ & $0,11 \%$ & $0,12 \%$ & $0,06 \%$ & $0,15 \%$ & $0,03 \%$ & $0,00 \%$ \\
\hline $\begin{array}{c}\text { The share of } \\
\text { insurance } \\
\text { indicators of the } \\
\text { Khabarovsk } \\
\text { territory in } \\
\text { relation to the Far } \\
\text { Eastern Federal } \\
\text { district }\end{array}$ & $39,2 \%$ & $83,6 \%$ & $100 \%$ & $43,8 \%$ & $83,3 \%$ & $8,4 \%$ & $0,0 \%$ \\
\hline
\end{tabular}

* The table is compiled by the author on the basis of Rosstat data in Table 2.

Thus, the potential for the development of voluntary investment and accumulative life insurance exists in the Russian insurance market today, and is only at the stage of its initial development.

Russian insurance companies today offer cumulative life insurance not only in rubles, but also in foreign currency. In the period from 2017 to 2018 , there was a sharp decrease in premium payments under voluntary life insurance contracts by almost two times (by $83 \%$ ), while in the compulsory insurance sector, state and personal insurance coincided, an increase of $43 \%[15,16]$.

\section{CONCLUSION: IMPROVING THE ACCUMULATIVE LIFE INSURANCE MARKET IN RUSSIA}

All the problems in the insurance sector, both in the far Eastern Federal district and in Russia as a whole, are also associated with dynamic, rather complex processes of digitalization of the Russian economy. The insurance sector of the far Eastern Federal district is undergoing difficult tests, mostly due to the reduced quality of life of its 
population in comparison with the quality of life of citizens living in the Western part of Russia:

1) Voluntary personal insurance (accumulative and investment) is at the very beginning of its development (after the major collapse of this type of insurance in the collapse of the USSR). The population is simply afraid to use the tool of accumulative life insurance, and investment life insurance is not clear to the average resident of the country; in addition, the contours of these two types of insurance are still blurred even at the legislative level, in General, the study of this issue requires additional research;

2) The low use of personal insurance tools for residents of the far Eastern Federal district may be associated with a low quality of life, in comparison with national indicators (including housing affordability, housing conditions, level of education, level of medical care, its availability, etc.);

3) Residents of the far Eastern Federal district do not see the possibility of accumulative insurance for their future pension savings, and do not take this financial instrument seriously as a means of forming personal financial reserves. This may be due to the low income of the population, its indebtedness, and psychological preferences for using Bank deposits-all this requires additional research, including through sociological surveys, and is not the purpose of this analysis.

4) Also summarizing the available information, it can be noted that the Federal state statistics service does not provide open data for all subjects of the Far East, so the insurance structure of the far Eastern Federal district requires additional research. And, for further development of the insurance sector in the region, it is necessary to conduct educational activities in the region, based on additional socio-economic research among the population and businesses regarding the attitude to insurance as a financial instrument of protection and investment.

Summarizing the above, the market of personal insurance, including accumulative life insurance, is developing dynamically in our country. The Central Bank of Russia has done serious work to clear the insurance market of unreliable companies. The Central Bank of the Russian Federation has developed a concept for improving investment life insurance contracts. The changes will stop the growth of unfair sales of this product. To verify compliance with the requirements, the Bank of Russia will monitor transactions for the purchase of life insurance policies, especially in the field of investment life insurance, as a form of insurance that has blurred boundaries, for example, policyholders are not always informed that investing is not a guaranteed income, i.e., when investing, you can both earn and lose money; individuals do not always understand that the mechanism for calculating interest on a Deposit and the percentage of investment on a coli policy are different mechanisms.

\section{ACKNOWLEDGMENT}

This work was supported by Far-East Institute of management, branch of the Russian Presidential
Academy of National Economy and Public Administration (hereinafter RANEPA), Department of mathematical methods and information technologies, Khabarovsk 680000, Russia.

\section{REFERENCES}

1. History of insurance development in Russia, Website of the representative office of the all-Russian Union of insurers in the Siberian Federal district, Available at: http://sib-insur.ru/ofni02-1.htm.

2. History of insurance and reinsurance, Website about insurance and risk management, January 21, 2020, Available at: http://www.askins.ru/index.php/story-i.

3. About the company, Rosgosstrakh, January 09, 2019, Available at:

http://www.rgs.ru/about/information/index.wbp.

4. Ingosstrakh, Company history, November 12, 2019, Available at:

http://www.ingos.ru/ru/company/company-history/.

5. Official site the company Medlife, Insurance company of the Grawe, Updated on November 26, 2019, Available at: https://www.medlife.net/ru/company/.

6. Official site the 8 Biggest Life Insurance Companies (PRU, MET), Updated on November 19, 2019, Available at:

https://www.investopedia.com/articles/personalfinance/092915/biggest-life-insurance-companiesus.asp/.

7. Central Bank of the Russian Federation, Available at: http://www.cbr.ru/.

8. Insurance Reference portal, Updated on July 15, 2019, Available at: http://risk-insurance.ru.

9. The Agency of insurance news, Updated on July 22, 2019, Available at: http://www.asn-news.ru.

10. Insurance today, Updated on March 23, 2020, Available at: http://www.insurinfo.ru/statistics/analytics.

11. N.I. Bykanova, A.S. Cherkashina, Insurance market of Russia: problems and directions of development, Young scientist 10 (2017) 204-207. 
12. Review of insurers' activities in 2018, Official data of the Federal state statistics service, 2019, Available at: https://www.gks.ru/storage/mediabank/strah-org_n.htm.

13. Official data of the Federal state statistics service, April 30, 2020, Available at:

https://www.gks.ru/folder/11192.

14. Official data of the Federal state statistics service, Updated on July 01, 2019, Available at:

https://www.gks.ru/working_conditions.

15. Yu.V. Neradovskaya, Russian Insurance market: some characteristics of extensive and intensive development, Finance and business 2 (2011) 103-113.

16. Statistical indicators and information about individual subjects of the insurance market, CBR, April 30, 2020, Available at:

http://cbr.ru/finmarkets/?PrtId=sv_insurance. 